\title{
WILLIAM ELLIOT GRIFFIS, CLASS OF 1869
}

\author{
BY ARDATH W. BURKS \\ Professor of Political Science, Rutgers University
}

\begin{abstract}
AMOST one hundred years before "Point Four" was coined, a century before technical assistance, the equivalents of American peace corpsmen played significant roles in the emergence in the nineteenth century (to be sharply distinguished from what is usually assumed to be its Westernization) offers us today an interesting case study in the problem of inter-cultural relations, and in their effects on development.
\end{abstract}

The fact that William Elliot Griffis played a significant part in a process of change in both Japan's status and American attitudes, does not really make him unique. By the time Griffis arrived in Japan, there had been numerous encounters between "yankees and samurai." Preceding him were Perry, Harris, LeGendre, and Dennison. Even Rutgers offered an earlier pioneer, Robert H. Pruyn (Class of I 833), the first Minister-Resident. Guido Verbeck, who was instrumental in getting Griffis to Japan, and David Murray, who in 1873 followed Griffis from Rutgers to Japan, doubtless had far greater impact on the critical field of education. William S. Clark of Massachusetts (known throughout Japan even today for his "Boys Be Ambitious" slogan), after a briefer visit, left Hokkaido looking far more like New England than Japan. And Richard Henry Brunton, who left lighthouses strung all along Japan's coast, was celebrated by Griffis himself as perhaps most typical of the early, so-called yatoi, the foreign employees. ${ }^{3}$

Not that Griffis has been forgotten in Japan. Rather, he is being rediscovered by both Japanese and Americans. Indeed, he is far

\footnotetext{
1 "Missions to Japan," in Merle Curti and Kendall Birr, Prelude to Point Four (Madison, Wisconsin: I954).

${ }^{2}$ Foster Rhea Dulles, Yankees and Samurai; America's Role in the Emergence of Modern Japan (New York: Harper \& Row, 1965).

${ }^{3}$ (Typescript) Richard H. Brunton, Pioneer Engineering in Japan, with a Preface by W. E. Griffis ( 300 pp.), Griffis Collection, Special Collections, Rutgers University Library (hereinafter cited as $G C$, RUL).
} 
better known today in the provincial capital of Fukui, on the Japan Sea coast, than on the Rutgers campus." Griffis always took pride in the claim that he was the only foreigner who lived in the castletown of a daimyo (feudal lord) in the interior, and who saw and described the transition from a feudal system to modernity. His vivid, first-hand accounts have become primary material in the hands of scholars concerned with that transition.

It is true that Dr. Griffis played an important part in the introduction of western science into the new Japanese curriculum. He was among the first foreigners to teach modern chemistry and physics to Japanese (in Fukui); and later, he was called to the capital (in Tokyo) to teach natural science at the Daigaku Nankō, one of the predecessors of Tokyo University. Nevertheless, other foreigners may be said to have contributed more to the introduction of science in Japan. ${ }^{5}$

Today it is increasingly recognized that the major contribution of Griffis was in his role as our first "Old Japan Hand." After only four short years of educational services to emergent Japan, he returned to America. For fifty-two years thereafter, prior to a brief revisit to East Asia and to his death, Dr. Griffis devoted himself to the writing of innumerable books, hundreds of articles, and contributions to encyclopedias; he delivered some 3,000 lectures on Asia; and he kept in constant touch with particularly Japanese affairs. He was one of America's first scholarly-and at the same time, popular-writers to project an image of the cultures of East Asia on the consciousness of informed Americans. ${ }^{6}$ On the occasion

4 The author was startled, in 1959, to discover in Fukui a rich collection of documents on Griffis in the Fukui Prefectural Library; memorabilia and exhibits in the Fukui City Museum, where there is also a sun dial marking the return and triumphal visit of Griffs, in 1927 ; and a huge stone marker indicating the site of the residence of Griffis, in the nineteenth century. A recent indication of revived interest in the so-called yato $i$, and especially in Griffis, is contained in the volume published by a Japanese scholar, Umetani Noboru, Oyatoi gaikokujin; Meiji Nihon no wakiyaku-tachi (Foreign employees; supporters of Meiji Japan) (Tokyo: Nihon Keizai Shimbunsha, 1965). Prof. Umetani has visited Rutgers and has examined the Griffis Collection.

${ }^{5}$ For example, the Dutch chemist, K. W. Gratama, and two British chemists, E. Divers and R. W. Atkinson; see (offprint), Masao Watanabe, "The Early Influence of American Science on Japan," International Relations of American Science (Paris: Hermann, 1962), pp. 197-208.

${ }^{6}$ In 1928 , in accordance with his directions, many of his books and his accumulation of letters, clippings, manuscripts, pamphlets, and hasty jottings were forwarded to the Rutgers University Library. See Ardath W. Burks \& Jerome Cooperman, "The William Elliot Griffis Collection," The Journal of A sian Studies, XX (Nov., 1960), 6I-69. 
of his death, a major newspaper commented on his role as "Interpreter of a Nation" and on his career:

This experience enabled Dr. Griffis to interpret Japan with peculiar insight. The decorations with which he was showered by the Japanese Government indicate the value which was attached to his services as an interpreter by the Japanese themselves. He was one of the little band of early visitors to the country that gradually made Japan known to the West. ${ }^{7}$

William Elliot Griffs was born in Philadelphia September I7, I 843, fourth child of John Limeburner Griffis ( I 804-I 879). His father was a coal trader, who made frequent trips to Europe, Africa, the Philippines, and China. His mother was Anna Maria (Hess) Griffis (I812-I 872), a very pious woman who taught Sunday school in Philadelphia. In the I 840's she attended commencement at Rutgers College and resolved, should one of her sons be a minister, that Rutgers would be his alma mater. ${ }^{8}$ William's eldest brother, Montgomery Patterson Griffis (1 840-1902), served in the merchant marine and had travelled to Europe, to South America, and to the East Indies. Margaret Quandril Clark Griffis (I838-I9I3) was his most affectionate sister and encouraged him throughout his life. Thus William had his eyes opened to the outside world by his father and brother; his family and inner religious life were nurtured by his mother and sister.

Much later in life, Griffis looked back and singled out two events in his youth, coincidences which predicted the future course of his own career. On April 6, 1850, when William was seven, his father took him to a pier on the Delaware to witness launching of the frigate, the U.S. Susquehanna (the ship which later became the flagship of Commodore Matthew C. Perry, who opened Japan in I 853 )..$^{9}$ On June 9, I 860 in Philadelphia, he saw the first Japanese Embassy, sent to ratify the commercial treaty concluded by Townsend Harris in I 858. Later he was to describe the visitors: "From the first, I took the Japanese seriously. In many respects they were our equals, in others they seemed to be our superiors." ${ }^{10}$

7 "Interpreter of a Nation," New York Evening Post, February 7, 1928; GC, RUL.

${ }^{8}$ W. E. Griffis, "Intimate Glimpse," Rutgers Alumni Quarterly, II (Apr., 1916), I 34.

${ }^{9}$ W. E. Griffs, The Mikado's Empire (New York: Harper \& Bros., I Ith ed., I 906), p. 677 .

${ }^{10}$ For a description of the mission, see Margaret C. Griffis Dairy (1858-60), GC, RUL; for his recollection, The Mikado's Empire, edition cited, p. 677. 
For several months after he was graduated from Central High School in Philadelphia, in June, I 859, William worked as an appientice in a jewelry firm. Meanwhile, he was attending church, prayer meetings, missionary societies, and Bible class at John Chambers' church. In I 863 , however, he broke with Chambers over the slavery issue, and for a time was in military service as a corporal in the 44th Regiment of the Pennsylvania Militia. About the same time, he transferred his letter to the Second Reformed Dutch Church, under the Rev. Thomas deWitt Talmage. ${ }^{11}$ There he first heard sermons by William Henry Campbell, President of Rutgers. Indeed, as Griffis noted, it was on May 24, 1863, that he listened to a Campbell sermon based on the text "If any man will be my disciple, let him take up his cross and follow me." ${ }^{12}$ The result of this moving message was a determination to enter the ministry and, with the support of the church, to study at Rutgers. After additional preparatory work, he was admitted to Rutgers on September 20, I 865.

There is no doubt from the record that William Elliot Griffis was an outstanding student at Rutgers. Noteworthy is the fact that, although he was preparing for the seminary, he elected the new scientific curriculum (begun in I 864).$^{13}$ While studying hard, he attended Campbell's sermons at Seminary Chapel, went to Bible class at the Dutch Reformed Church, and taught Sunday school at the First Presbyterian Church, New Brunswick. ${ }^{14}$ As an undergraduate, he was a member of Delta Upsilon fraternity, he joined the Philoclean Literary Society, with a classmate he planned a monthly publication (the first Targum), he won numerous oratorical contests, and in May, I869, he was elected to Phi Beta Kappa. Something of his outlook was revealed by a speech he made at class day exercises, May 25, I 869, when he proposed first, that students should

${ }^{11}$ W. E. Griffis, John Chambers, Servant of Christ and Master of Hearts and His Ministry in Philadelphia (Ithaca: Andrus \& Church, 1903), p. 121 .

${ }^{12}$ W. E. Griffis Diary (1862-64), GC, RUL.

${ }^{13}$ Griffis studied mathematics (arithmetic, geometry, trigonometry), astronomy (David Murray); chemistry, physics, botany (George H. Cook); Latin (deWitt T. Reiley); Greek (David Cole); Greek philosophy (Jacob Cooper), rhetoric, aesthetics, philosophy (T. Sanford Doolittle); German, French (Gustavus Fischer); Hebrew (President Campbel1); and history (George W. Atherton); Kaneko Tadashi (manuscript), "Griffis and Japanese Students," GC, RUL.

${ }^{14}$ W. E. Griffis Diary ( $\left.1864-70\right), G C$, RUL. 
prepare to enter public life; and second, that ladies should have educational facilities equal to those enjoyed by men. ${ }^{15}$

It must have been in the Fall of I 866 that Griffis met the first two Japanese students brought to New Brunswick by the Rev. John Mason Ferris, Secretary of the Board of Foreign Missions, New York. ${ }^{16}$ Two years later, Kusakabe Taro entered Rutgers and Griffis taught him Latin. In I 870 before his graduation, Kusakabe died of tuberculosis. Griffis attended his funeral (and later, when he visited Japan, delivered Kusakabe's Phi Beta Kappa key to his parents) ${ }^{17}$ In I $869-70$, Griffis met dozens of Japanese visitors, some who stayed at his home in Philadelphia. Meanwhile, he compiled other impressions of Japan: his classmate, Robert C. Pruyn, invited him to his home in Albany where he met the distinguished father, Robert H. Pruyn. ${ }^{18}$

After his graduation and a summer trip with Margaret through Europe (only the first of his many trips across the Atlantic), William Griffis studied at New Brunswick Theological Seminary (where he took his M.A.), taught at Rutgers Preparatory School, and also preached at Knox Memorial Chapel, New York City. It was on September 6, 1870 that he heard of an inquiry, a letter originally from Guido Verbeck in Japan relayed through J. M. Ferris, President Campbell, and Professor D. T. Reiley: "For a young man, single not a Minister, to go to Japan to teach the Natural Sciences and organize educational work generally. The time is for three years, salary $\$ 2,400$, house and horse. . . ."19 Verbeck had added that a young bachelor "of careful habits" could live nicely on $\$ 800$ a year; he ought to be "of firm and practical piety," be-

\footnotetext{
${ }_{15}$ The speaker himself was later quick to take credit for the idea of the women's college, founded as New Jersey College for Women in 1918 (now called Douglass College), in "N.J.C. Started in 1869 ," Campus News, New Jersey College for Women, IV. I I (Dec. I4, I923), signed "W.E.G." GC, RUL.

${ }^{16}$ Although the Griffis Diary is not completely clear on this point, he later wrote (in The Mikado's Empire) that he had tutored the students who were, under assumed names, Ise (Yokoi Saheida) and Numagawa (Yokoi Daihei).

${ }^{17}$ W. E. Griffis Diary (1864-70), entries for Apr. 13, 15, 1870, GC, RUL. Kusakabe was, beyond doubt, the first Japanese to be elected to Phi Beta Kappa. The key, and also his college textbooks, now rest in the Fukui City Museum, where the author has examined them.

${ }^{18}$ W. E. Griffis Diary (1864-70), entry for Nov. 28, 1870, GC, RUL.

19 D. T. Reiley to W. E. Griffis, Sept. 6, 1870 , in W. E. Griffis Scrapbook of Fukui I 87 r, GC, RUL, Letter.
} 
cause the temptations were fearful and, indeed, "there had been very few, outside of ministers and missionaries who had not fallen."20

At first Griffis hesitated, but on the prodding of Pruyn and his father, Ferris, Reiley, and President Campbell, on October I he agreed to go. His reasoning at the time gave an accurate clue to mixed motivations:

I can study and be ordained there, and God willing, return to my native land, only one year later than if $I$ stayed. Besides the grand opportunities and culture, travel and a good climate, and being under the special protection of the prince, I can not only study on my theology but collect materials to write a book. I can support my family at home, at least pay the rent, and carpet the floors and rent a handsome home, too."21

As a matter of fact, this may well have been a typical, candid description of the feelings of many of those moved by what we now call "the American sense of mission." On November I3, I 870 , he left Philadelphia, crossed the continent by train, on December I sailed from San Francisco on a steamer, and on December 29 arrived in Yokohama. ${ }^{22}$

After brief visits and inspections in Yedo (modern Tokyo), on February I 7, I871, Griffis went by sea to Kobe and Osaka, overland to Lake Biwa which he crossed by boat, and arrived in Fukui, March 4. It was this travel that he later described so vividly in "First Glimpses of Japan," in his most famous book, The Mikado's Empire. And it was this experience too that taught him to be relatively objective, in truth, one of our first comparative historians. At one point he put down this remarkable paragraph:

How pleasant it would be to mention in this book nothing but the beautiful! How easy to let our glamoured eyes see naught but beauty and novelty! Why not paint Japan as a land of peerless natural beauty, of polite people, of good and brave men, of pretty maidens and gentle women? Why bring in beggars, bloody heads, loathsome sores, scenes of murder, assassins' bravery, and humanity with all nobility stamped out by centuries of despotism? Why not? Simply because homely truth is better than gilded falsehood. Only because it is a sin to conceal the truth when my countrymen, generous to believe too well, and led astray by rhetorical deceivers

${ }^{20} \mathrm{G}$. F. Verbeck to J. M. Ferris, Secretary of the Foreign Board of Missions, July $2 \mathrm{I}$, I 870 , Box 747.3, New Brunswick Theological Seminary Library, Letter.

21 W.E.G. to M. C. Griffis, September 26, $1870, G C$, RUL, Letter.

22 "Fukui Notes" (1870-74), GC, RUL. 
and truth-smotherers, have the falsest idea of Japan, that only a pen like a probe can set right. ... I give the true picture of Japan in $187 \mathrm{I}^{23}$

Indeed, it was this relative detachment which was to set William Elliot Griffis so much apart, both in his work in Japan and especially, in his long writing career after his return. Imbued with a sense of mission, he was nonetheless not an ordinary missionary; an alien in a strange land, he was sympathetic with the Japanese and bitterly criticized foreigners; dedicated to detached teaching and to fundamental research in natural sciences, in political issues he took sides and remained a controversial figure. Meanwhile, while he taught and preached and argued, he observed Japanese life closely, took detailed notes, and reported his impressions in long letters written weekly to his sister Margaret. His first-hand account of Haihanchiken (abolition of feudal domains-establishment of prefectures, I 87I) is still among the most accurate, written by foreigner or Japanese, we have.

Now it is surprising to learn that William Elliot Griffis' first stay in Japan was so short: in Fukui he organized, taught, tutored, studied, and wrote only one year, returning to Tokyo in January, 1872. He was supposed to open a polytechnical school under the new Department of Education, at the capital, but meanwhile Japan's plans and Japanese education had radically changed. Although he continued to teach (chemistry, physiology, and comparative philology) at the Daigaku Nanko until his departure, in July, I 874, his relations with the Japanese Government grew ragged, were even marked by bitterness. ${ }^{24}$ In fact, he was not to return to Japan until many years later, in 1927 .

After his return to America, William Elliot Griffis plunged back into preparation for the ministry, and was graduated from Union Theological Seminary in 1877 . Two years later, he married Katherine L. Stanton, who helped him in his first pastorate in the First

${ }^{23}$ Book II, "Personal Experiences, Observations, and Studies in Japan, I $870-1874$," The Mikado's Empire (New York: Harper \& Bros., 6th ed., I890), p. 36r.

${ }^{24}$ Arguments arose, as they have so often since, out of failure of communication between the foreign guest and the Japanese; for his side of the case, see W.E.G. to Mombushō [Ministry of Education], Tokyo, September 3, I872 (his copy), GC, RUL, Letter. During this period, Griffis was instrumental in getting his sister, Margaret, invited to Japan, but both concluded that her services were not adequately used toward their dream, the establishment of regular education for women; see M. C. Griffis to her sisters, Tokyo, Aug. 20, Sept. 2 1, Oct. 30, 18 72 , GC, RUL, Letters. 
Reformed Church, Schenectady, New York (I 877-1886). There followed assignments in Shawmut Congregational Church, Boston (1886-1893) and in First Congregational Church, Ithaca, New York ( $1893^{-1903) . ~ U n i o n ~ C o l l e g e ~ c o n f e r r e d ~ u p o n ~ h i m ~ h i s ~ d e g r e e ~}$ of Doctor of Divinity in I 884 .

From r 903 on, Griffis established his reputation as a lecturer and writer. His alma mater, Rutgers College, in i 899 had already recognized his stature by conferring upon him the degree of L.H.D. And the Japanese Government in 1903 belatedly honored his contributions to international understanding by giving him the Fourth Order of the Rising Sun.

Dr. Griffis by no means confined himself to study, writing, and lecturing on the Far East. He became active in the field of local history, serving as President of the DeWitt Historical Society (Tompkins County, New York); he was a member of the American Historical Association and of the U.S. Naval Institute. He made eleven trips to Europe, nine including preaching tours of Great Britain. In 1909, having just completed an extended edition of Motley's Dutch Netherlands, he visited Holland to erect historical tablets, including one at Utrecht on behalf of Rutgers College. He was a loyal and lifelong member of Rutgers alumni associations.

As a well-known publicist, writing on Japanese affairs, Dr. Griffis often displayed the ambivalence which has so marked relationships between Japan and the United States in general. He sometimes found himself on opposite sides of a controversy, particularly with regard to Japan's administration of Korea after annexation in $1910 .^{25}$

At the age of 84 , fifty-seven years after his first visit, Dr. William Elliot Griffis returned triumphantly to Japan to be overwhelmed with honors. As he wrote, “. . . the returning pilgrim felt very much like the living creature in the book of Revelation, which 'had eyes

\footnotetext{
${ }^{25}$ For example, at first dedicated to the side of the Japanese in the issue over treaty revision (in the late nineteenth century), Griffis wrote articles praising the quality of iustice in Japan. Then, when notorious Peace Preservation Laws began harassing liberals whom he knew, the outraged Griffs vigorously (and anonymously) denounced Japan; Ardath W. Burks, "Coercion in Japan': A Historical Footnote," The Journal of the Rutgers University Library, XV (June I952) 36-37, 50-51. For his ambivalence on Korea, see Ardath W. Burks \& Jerome Cooperman, "Dr. William Elliot Griffs (I 8431928) and 'The Hermit Nation,'" The Journal of Asiatic Studies (Seoul, Korea) III (June, 1960), 177 .
} 
before and behind'." ${ }^{26}$ Using a special railroad car provided by the Government, he visited all important Japanese cities and marvelled at the nation's progress. When he visited Fukui, the city's dignitaries and some I0,000 school children turned out to help him celebrate a 4-day holiday. To this day, in this city on the Japan Sea coast, older residents recall the homecoming. Griffis spent eight months in Japan, culminating with a farewell by the Tokyo Municipality presided over by Mayor Nishikubo. In characteristic fashion, Dr. Griffis left a parting warning about the need "... above all of ever choosing and discriminating between the good and the dross, and that everything foreign was not good just because it was foreign." ${ }^{27}$ Just before departure, he was granted an audience with the Emperor and was given the Third Order of the Rising Sun.

While he was in the Far East for the last time, Dr. Griffis paid his first visit to the mainland, travelling through Manchuria and Korea. ${ }^{28}$ When he returned to the United States, he was typically forthright and proved that he could, of course, be wrong. $\mathrm{He}$ stated,

In regard to a possible war between the United States and Japan, all the hostile war spirit is on this side of the Pacific Ocean, and is manufactured, in my opinion, by American munition makers. ${ }^{29}$

Fortunately, William Elliot Griffis never lived to see the rising tension between Japan and America leading eventually to war. On February 5, 1928, in Winter Park, Florida, he died of heart failure. Surviving him were three children by his first marriage: Stanton Griffis, broker (New York); Elliot Griffis, composer-pianist (Laguna Beach, California); and Mrs. Russell Iridell (New York). At his side was his second wife, Mrs. Francis (King) Griffis of Pulaski, New York.

The most valuable and lasting monument to Dr. Griffis consists of his voluminous writings, articles, notes, and correspondence.

${ }^{26}$ Edith A. Sawyer, "Dr. Griffis, Educator, Helped 'Relay Foundation' of Japan," New York Herald Tribune, February i 9, 1928, GC, RUL.

${ }^{27}$ "Tokyo City Stages Farewell Meeting for Dr. W. E. Griffs," The Japan Times छ Mail, June 29, 1927, GC, RUL.

${ }^{28}$ Curiously, Griffis became America's first expert on Korea before he ever visited the peninsula. He first published Corea: the Hermit Nation in I 882 and it subsequently ran through eight editions.

29 "Japan Pays U.S. Teacher High Honors," San Francisco Chronicle, July I 7, 1927, $G C$, RUL. 
Following his wishes, in 1928 his library containing some 3,500 books and his papers were turned over to the Rutgers University Library. Most dealt with Japan, China, and Korea, but there were also items on American history, biography, European origins, New York and Pennsylvania local history. A bibliography of his own writing would certainly include some 50 years' contributions to the Christian Intelligencer, drafts of pieces for periodicals and encyclopedia, I 8 books on Japan, 4 on Korea, 3 on the pilgrim fathers, 6 on Holland, and various works on China, Belgium, Scotland, and England. ${ }^{30}$

In addition to being America's first "Old Japan Hand," Dr. William Elliot Griffis obviously put some of the very first "scratches on the minds" of our ancestors, in the late nineteenth century just turning their attention from America's frontier to the boundaries of the world.

30 "Rutgers Receives 3,500 Volumes; Library of the Late Rev. W. E. Griffis," New Brunswick, N.J. The Daily Home Nequs, November 27, 1928, GC, RUL. A partial, representative list of his books includes: The Mikado's Empire (rst ed., 1876); Corea: the Hermit Nation (Ist ed., I882); Matthew Calbraith Perry ( 1887 ); Honda, the Samurai (1890); Brave Little Holland-What She Taught Us (1894); The Religions of Japan (1895); Townsend Harris-First American Envoy to Japan (1895); The Student's Motley (1898); Verbeck of Japan (1900); China's Story in Myth, Legend, Art and Annals (1910); Belgium, the Land of Art (1912); Hepburn of Japan, Pioneer of Science and Religion (1912); Bonnie Scotland and What We Owe Her (I916). 